\title{
Modeling and optimization of parameters for minimizing surface roughness and tool wear in turning Al/SiCp MMC, using conventional and soft computing techniques
}

\author{
Tamang, S.K. ${ }^{a}$, Chandrasekaran, M..$^{\mathrm{a},{ }^{*}}$ \\ ${ }^{a}$ Mechanical Engineering Department, North Eastern Regional Institute of Science and Technology, Nirjuli, India
}

\section{A B S T R A C T}

Aluminium alloy with silicon carbide particulate $(\mathrm{Al} / \mathrm{SiCp})$ reinforced metal matrix composite (MMC) are used within a variety of engineering applications due to their excellent properties in comparison with non-reinforced alloys. This presented work attempted the development of predictive modeling and optimization of process parameters in the turning of $\mathrm{Al} / \mathrm{SiCp} \mathrm{MMC}$ using a titanium nitride (TiN) coated carbide tool. The surface roughness $R_{\mathrm{a}}$ as product quality and tool wear $V B$ for improved tool life were considered as two process responses and the process parameters were cutting speed $v$, feed $f$, and depth of cut $d$. Two modeling techniques viz., response surface methodology (RSM) and artificial neural network (ANN) were employed for developing $R_{\mathrm{a}}$ and $V B$ predictive models and their predictive capabilities compared. Four different RSM models were tried out viz., linear, linear with interaction, linear with square, and quadratic models. The linear with interaction model was found to be better in terms of predictive performance. The optimum operating zone was identified through an overlaid contour plot generated as a response surface. Parameter optimization was performed for minimizing $R_{\mathrm{a}}$ and $V B$ as a single objective case using a genetic algorithm (GA). The minimum $R_{\mathrm{a}}$ and $V B$ obtained were $2.52 \mu \mathrm{m}$ and $0.31 \mathrm{~mm}$, respectively. Optimizations of multi-response characteristics were also performed employing desirability function analysis (DFA). The optimal parameter combination was obtained as $v=50 \mathrm{~m} / \mathrm{min}, f=0.1 \mathrm{~mm} / \mathrm{rev}$ and $d=0.5 \mathrm{~mm}$ being the best combined quality characteristics. The prediction errors were found as $4.98 \%$ and $3.82 \%$ for $R_{\mathrm{a}}$ and $V B$, respectively, which showed the effectiveness of the method.
\end{abstract}

\section{ARTICLE INFO}

Keywords:

Metal matrix composite

Surface roughness

Tool wear

Response surface methodology

Artificial neural network

Genetic algorithm

Desirability function analysis

*Corresponding author:

mchse1@yahoo.com

(Chandrasekaran, M.)

Article history:

Received 28 July 2014

Revised 29 March 2015

Accepted 10 April 2015 


\title{
APEM
}

\section{Modeliranje in optimizacija obdelovalnih parametrov za minimizacijo površinske hrapavosti in obrabe orodja pri struženju Al/SiCp MMC z uporabo konvencionalnih in mehkih računalniških pristopov}

\author{
Tamang, S.K. ${ }^{a}$, Chandrasekaran, M. $^{\mathrm{a},{ }^{*}}$ \\ ${ }^{a}$ Mechanical Engineering Department, North Eastern Regional Institute of Science and Technology, Nirjuli, India
}

\section{POVZETEK}

Aluminijeve zlitine, s karbidnimi delci (Al/SiCp) okrepljeni kompoziti s kovinsko osnovo (MMC), se uporabljajo pri številnih inženirskih aplikacijah zaradi odličnih lastnosti v primerjavi z neokrepljenimi zlitinami. Ta raziskava je bila namenjena razvoju modeliranja in optimizacije procesnih parametrov pri struženju Al/SiCp MMC s karbidnim orodjem, prevlečenim s titanovim nitridom (TiN). Odziva sistema sta bila površinska hrapavost $R_{\text {a }}$ in obraba orodja $V B$. Procesni parametri so bili rezalna hitrost $v$, podajanje $f$ in globina reza $d$. Za razvoj napovedovalnih modelov $R_{\mathrm{a}}$ in $V B$ sta bili uporabljeni dve tehniki modeliranja, in sicer metodologija odzivnih površin (RMS) in umetne nevronske mreže (ANN). Preizkušeni so bili štirje različni modeli RSM, in sicer liearni, linerani s soodvisnostjo, linerano-kvadratni in kvadratni. Linearni model s soodvisnostjo je pokazal dobre lastnosti glede kakovosti napovedovanja. Optimalno delovno področje je bilo določeno s pomočjo konturnih grafov ustvarjenih kot odzivne površine. Narejena je bila enokriterijska optimizacija parametrov za minimizacijo $R_{\mathrm{a}}$ in $V B \mathrm{z}$ uporabo genetskega algoritma (GA). Najmanjši dobljeni $R_{\text {a }}$ oziroma $V B$ sta bili $2.52 \mu \mathrm{m}$ oziroma $0.31 \mathrm{~mm}$. Narejena je bila tudi optimizacija značilnosti pri več odzivih s pomočjo metode DFA. Optimalna kombinacija parametrov je bila: $v=50 \mathrm{~m} / \mathrm{min}, f=0.1 \mathrm{~mm} / \mathrm{rev}$ in $d$ $=0.5 \mathrm{~mm}$. Napaka pri napovedovanju je bila $4.98 \%$ oziroma $3.82 \%$ za $R_{\mathrm{a}}$ oziroma $V B$, kar kaže na učinkovitost predlagane metode.
\end{abstract}

\section{PODATKI O ČLANKU}

Ključne besede:

Kompoziti s kovinsko osnovo

Obraba orodja

Metodologija odzivnih površin

Umetne nevronske mreže

Genetski algoritem

Analiza funkcije koristnosti

*Kontaktna oseba: mchse1@yahoo.com

(Chandrasekaran, M.)

Zgodovina članka:

Prejet 28. julija 2014

Popravljen 29. marca 2015

Sprejet 10. aprila 2015 


\section{References}

[1] Allison, J.E., Cole, G.S. (1993). Metal-matrix composites in the automotive industry: Opportunities and challenges, Journal of the Minerals, Metals \& Materials Society, Vol. 45, No. 1, 19-24, doi: 10.1007/BF03223361.

[2] Arokiadass, R., Palanirajda, K., Alagumoorthi, N. (2011). Predictive modeling of surface roughness in end milling of Al/SiCp metal matrix composite, Archives of Applied Science Research, Vol. 3, No. 2, 228-236.

[3] Yuan, Z.J., Geng, L., Dong, S. (1993). Ultra precision machining of SiCw/Al composites, CIRP Annals - Manufacturing Technology, Vol. 42, No. 1, 107-109, doi: 10.1016/S0007-8506(07)62403-2.

[4] Davim, J.P. (2003). Design of optimisation of cutting parameters for turning metal matrix composites based on the orthogonal array, Journal of Materials Processing Technology, Vol. 132, No. 1-3, 340-344, doi: 10.1016/S09240136(02)00946-9.

[5] Muthukrishnan, N., Davim, J.P. (2009). Optimization of machining parameters of Al/SiC-MMC with ANOVA and ANN analysis, Journal of Materials Processing Technology, Vol. 209, No. 1, 225-232, doi: 10.1016/i.jmatprotec. 2008.01.041.

[6] Palanikumar, K., Karthikeyan, R. (2006). Optimal machining conditions for turning of particulate metal matrix composites using Taguchi and response surface methodologies, Machining Science and Technology, Vol. 10, No. 4, 417-433, doi: 10.1080/10910340600996068.

[7] Rajasekaran, T., Palanikumar, K., Vinayagam, B.K. (2011). Application of fuzzy logic for modeling surface roughness in turning CFRP composites using CBN tool, Production Engineering, Vol. 5, No. 2, 191-199, doi: 10.1007/s11740-011-0297-y.

[8] Palanikumar, K., Davim, J.P. (2009). Assessment of some factors influencing tool wear on the machining of glass fibre-reinforced plastics by coated cemented carbide tools, Journal of Materials Processing Technology, Vol. 209, No. 1, 511-519, doi: 10.1016/i.jmatprotec.2008.02.020.

[9] Chandrasekaran, M., Devarasiddappa, D. (2012). Development of predictive model for surface roughness in end milling of Al-SiCp metal matrix composites using fuzzy logic, World Academy of Science, Engineering and Technology, Vol. 6, No. 7, 928-933.

[10] Thiagarajan, C., Sivaramakrishnan, R., Somasundaram, S. (2011). Cylindrical grinding of SiC particles reinforced aluminium metal matrix composites, ARPN Journal of Engineering and Applied Sciences, Vol. 6, No. 1, 14-20.

[11] Davim, J.P., Reis, P., António, C.C. (2004). Experimental study of drilling glass fiber reinforced plastics (GFRP) manufactured by hand lay-up, Composites Science and Technology, Vol. 64, No. 2, 289-297, doi: 10.1016/S02663538(03)00253-7.

[12] Basavarajappa, S., Chandramohan, G., Prabu, M., Mukund, K., Ashwin, M. (2007). Drilling of hybrid metal matrix composites - Workpiece surface integrity, International Journal of Machine Tools and Manufacture, Vol. 47, No. 1, 92-96, doi: 10.1016/j.ijmachtools.2006.02.008.

[13] Chandrasekaran, M., Devarasidappa, D. (2014). Artificial neural network modeling for surface roughness prediction in cylindrical grinding of Al-SiCp metal matrix composites and ANOVA analysis, Advances in Production Engineering \& Management, Vol. 9, No. 2, 59-70, doi: 10.14743/apem2014.2.176.

[14] Hocheng, H., Tsao, C.C. (2005). The path towards delamination-free drilling of composite materials, Journal of Materials Processing Technology, Vol. 167, No. 2-3, 251-264, doi: 10.1016/i.jmatprotec.2005.06.039.

[15] Tsao, C.C., Hocheng, H. (2008). Evaluation of thrust force and surface roughness in drilling composite material using Taguchi analysis and neural network, Journal of Material Processing Technology, Vol. 203, No. 1-3, 342-348, doi: 10.1016/i.jmatprotec.2006.04.126.

[16] Mukherjee, I., Ray, P.K. (2006). A review of optimization techniques in metal cutting processes, Computers \& Industrial Engineering, Vol. 50, No. 1-2, 15-34, doi: 10.1016/i.cie.2005.10.001.

[17] Wang, X., Jawahir, I.S. (2005). Optimization of multi-pass turning operations using genetic algorithms for the selection of cutting conditions and cutting tools with tool-wear effect, International Journal of Production Research, Vol. 43, No. 17, 3543-3559, doi: 10.1080/13629390500124465.

[18] Öktem, H., Erzurumlu, T., Kurtaran, H. (2005). Application of response surface methodology in the optimization of cutting conditions for surface roughness, Journal of Materials Processing Technology, Vol. 170, No. 1-2, 11-16, doi: 10.1016/i.jmatprotec.2005.04.096.

[19] Pawade, R.S., Joshi, S.S. (2011). Multi-objective optimization of surface roughness and cutting forces in highspeed turning of Inconel 718 using Taguchi grey relational analysis (TGRA), The International Journal of Advanced Manufacturing Technology, Vol. 56, No. 1-4, 47-62, doi: 10.1007/s00170-011-3183-z.

[20] Sahoo, A.K., Pradhan, S. (2013). Modeling and optimization of Al/SiCp MMC machining using Taguchi approach, Measurement, Vol. 46, No. 9, 3064-3072, doi: 10.1016/j.measurement.2013.06.001.

[21] Sahoo, A.K., Pradhan, S., Rout, A.K. (2013). Development and machinability assessment in turning Al/SiCp-metal matrix composite with multilayer coated carbide insert using Taguchi and statistical techniques, Archives of Civil and Mechanical Engineering, Vol. 13, No. 1, 27-35, doi: 10.1016/i.acme.2012.11.005.

[22] Gopalakannan, S., Thiagarajan, S. (2014). Optimization of machining parameters for EDM operations based on central composite design and desirability approach, Journal of Mechanical Science and Technology, Vol. 28, No. 3, 1045-1053, doi: 10.1007/s12206-013-180-x.

[23] Kılıçkap, E., Çakır, O., Aksoy, M., İnan, A. (2005). Study of tool wear and surface roughness in machining of homogenised SiC-p reinforced aluminium metal matrix composite, Journal of Materials Processing Technology, Vol. 164-165, 862-867, doi: 10.1016/i.jmatprotec.2005.02.109.

[24] Dixit, P.M., Dixit, U.S. (2008). Modeling of metal forming and machining processes by finite element and soft computing methods, Springer-Verlag, London. 
[25] Kohli, A., Dixit, U.S. (2005). A neural-network-based methodology for the prediction of surface roughness in a turning process, The International Journal of Advanced Manufacturing Technology, Vol. 25, No. 1-2, 118-129, doi: 10.1007/s00170-003-1810-z.

[26] Goldberg, D.E. (1989). Genetic algorithms in search, optimization and machine learning, Addison-Wesley Longman Publishing Co., Boston, Massachusetts.

[27] Chandrasekaran, M., Muralidhar, M., Murali Krishna, C., Dixit, U.S. (2010). Application of soft computing techniques in machining performance prediction and optimization: A literature review, The International Journal of Advanced Manufacturing Technology, Vol. 46, No. 5-8, 445-464, doi: 10.1007/s00170-009-2104-x.

[28] Derringer, G., Suich, R. (1980). Simultaneous optimization of several response variables, Journal of Quality Technology, Vol. 12, No. 4, 214-219.

[29] Naveen Sait, A., Aravindan, S., Noorul Haq, A. (2009). Optimisation of machining parameters of glass-fibrereinforced plastic (GFRP) pipes by desirability function analysis using Taguchi technique, The International Journal of Advanced Manufacturing Technology, Vol. 43, No. 5-6, 581-589, doi: 10.1007/s00170-008-1731-y. 